\title{
THE ETHNOGRAPHICISATION OF ANGLO-AMERICAN ANTHROPOLOGY: CAUSES AND CONSEQUENCES
}

James Urry

\begin{abstract}
Anthropology, at least in terms of its emphasis on social and cultural life, is noted both within and outside the discipline for the quality of its ethnography. Ethnography, however, has come to mean different things within and outside anthropology. One dominant understanding is associated with ethnography as a distinct methodology involved with qualitative, local level research. Another concerns the product of such research - ethnographic accounts of social and cultural groups including the form of such texts as literary objects. How ethnography developed in the British and American traditions reveals how the discipline became more focussed on methodology and text than on theory. The contexts of this shift and its consequences for anthropological practice are considered with a suggestion that perhaps anthropologists are really ethnographers, not anthropologists, and perhaps a broader view of anthropology needs to be rediscovered.
\end{abstract}

Modern social and cultural anthropology in the Anglo-American tradition is dominated by a concern with ethnographic research and detailed ethnographic accounts published in articles and occasionally monographs. Doing ethnography in Britain and America is not only intimately connected with the very process of becoming an anthropologist, but also of being an anthropologist. In Anglo-American anthropology admission to the discipline usually requires a candidate to be initiated through a rite of passage that involves undertaking original ethnographic field research (Urry 1985). The ethnographic emphasis, however, extends well beyond these initiation rites. Research in anthropology is primarily based on first-hand ethnographic material subsequently analysed with reference to a variety of anthropological frameworks of explanation. Most published anthropological accounts concentrate on ethnographic issues, even 
if these are often rather grandly presented as innovative fashion statements, decorated with theoretical trinkets and claims to original designer status. A casual examination of most anthropological journals reveals a continued fascination with ethnographic detail and the majority of papers published are highly focussed on particular aspects of life in a single ethnographic situation. In fact, nearly all anthropological discussions are dominated by ethnography. Most anthropologists therefore possess a double identity as both an ethnographer and as an anthropologist.

Could it be, however, that anthropologists today are not really anthropologists at all - at least in the broader sense of the term once understood in the history of the discipline - but instead are just ethnographers? Such a proposition raises other questions. What exactly in anthropology's past was the relationship between anthropology and ethnography? ${ }^{1}$ Why is it that in the Anglo-American tradition today ethnography is so dominant in the research and writings of those who claim to be anthropologists when compared with anthropologists in other traditions such as the French, the Germans and others? Or to pose the question from the perspective of related disciplines, why are anthropologists also ethnographers while sociologists are not sociologists and sociographers and psychologists not psychologists and psychographers? ? $^{2}$ Today, although some sociologists, psychologists and an increasing number of researchers in other disciplines claim to do ethnography, a phrase generally meaning just 'I do qualitative research at a local level' and/or 'I write accounts of human life at the everyday level', these new 'ethnographers' are neither anthropologists by training, nor intent - and they do not try to identify themselves as such. 'Ethnographisation', it would seem, has spread beyond our discipline but without the same pattern of importance or a dual identity among its practitioners.

GEORGE STOCKING AND THE 'ETHNOGRAPHICISATION' OF ANGLO-AMERICAN ANTHROPOLOGY

The term 'ethnographicisation' was, I believe, first used by the noted historian of anthropology, George W. Stocking. For Stocking ethnographicisation refers to a tendency in Anglo-American anthropology to give increased attention' to 'localised populations that were the focus of ethnographic inquiry'. This produced, within their respective 'academic fieldwork tradition [s,] ... a more ethnographically particular anthropology' (1995:230) that involved the 'de-historicisation' of anthropological enquiry in favour of more synchronic research, a tendency that Stocking argues was not unique to anthropology but also occurred in closely related fields such as linguistics, physical anthropology and archaeology (1995: 231; 2001C: 316$)$. Ethnographicisation thus was 
part of a major paradigm shift in anthropology that included not only the 'dehistoricisation' but also the 'professionalisation' of the discipline. Stocking identifies a number of consequences of ethnographicisation. In terms of professionalism, anthropology was 'redefined in terms of the empirical study of particular ethnographic entities existing in the present' and 'practical social utility', in contrast to the conjectural speculations of the earlier evolutionists and contemporary diffusionists (1995: 231). In terms of theoretical emphasis, ethnographisation weakened the older "tenuous integration of "anthropology" (1995: 232) as a theoretical discipline and replaced it with an ethnographic integration that in Britain emphasised the idea of 'social structure' and in America the concept of 'culture' (1995: 230; 2001c:318). There was also a personalisation of ethnographic practice as the connection between the anthropologist and their subjects slipped from the 'Amongtha' to 'My People' (2001c:317).

The period Stocking is discussing is roughly that between 1900 and 1940, with a particular focus on the formative period between the two World Wars. I can find little fault with his argument and indeed my own more limited accounts of British anthropology of this period suggest a similar process (Urry 1984, 1993). But I think it is worthwhile re-examining the historical factors involved, relating the shifting meanings of ethnography to the changing ideas associated with the field of anthropology and revisiting the full implications of ethnographicisation for anthropology in the present, without being too 'presentist' in the process.

ETHNOLOGY/ANTHROPOLOGY - ETHNOGRAPHY/ANTHROPOGRAPHY:

EARLY FORMULATIONS

The term 'anthropology' was once primarily a theological term indicating the study of mortal humans and their affairs in relation to divinity, the sacred and the eternal. Only later did it acquire the secular sense with which it is largely associated today. The 1828 Webster's Dictionary defined anthropology as: '1. A discourse upon human nature. 2. The doctrine of the structure of the human body; the natural history or physiology of the human species. 3. The ...manner of expression by which the inspired writers attribute human parts and passions to God.' But in the history of anthropology as a discipline, the term anthropology was preceded in importance by the term 'ethnology'. Today in Anglo-American anthropology this term is somewhat archaic and in modern British anthropology is rarely used. But as interested individuals in France, Britain and the USA established institutions devoted to the study of humankind in the 1830s and 4OS, ethnology was the generally agreed upon term chosen to describe their activities. ${ }^{4}$ Those involved with ethnological 
study attempted to explain differences in custom, physical form and language in the context of the history of humankind and at this period tended to privilege language as the key to unlocking relationships between peoples in time and space (Stocking 1987). By 1855 Robert Latham could define ethnology as the 'relation of different divisions of mankind to each other' and argue that it was a science closely allied to anthropology which determined 'the relations of man to other members of the animal kingdom.' The idea of Man in Nature had begun to make its appearance, but in terms of analysis it was still subordinated to language and custom. Latham also contrasted ethnology with ethnography, the former being the 'speculative portion of the subject' and the latter the 'descriptive.' (1855:341).

By the middle of the nineteenth century, arguments about which was the better term to use to describe the study of man became a source of conflict between supporters of the older term 'ethnology' and the newly redefined term 'anthropology' (Stocking 1987). Supporters of a new and aggressive anthropology claimed to study the same set of features - custom, language and race - but gave preference to race as the determinant of the other variations. In Britain, this conflict was particularly intense in the 1860 s although not, as many believe, in the context of the emergence of Darwin's evolutionary ideas, even if Darwin's name was later critical to those who viewed anthropology as the study 'Man in Nature'. Instead, the disagreements occurred in the context of major socio-political events of the period when race, an absolute defining feature, became important in explaining European superiority as the industrial revolution produced a great technological divide between Europeans and others and European colonial expansion grew into imperialism. Anthropology became increasingly grounded in biology and race, combining that queen of nineteenth century science, Natural History, with a pugnacious sense of European superiority.

In France, discussions concerning the appropriate use of the various terms, 'anthropology', 'ethnology' and 'ethnography', were debated in the learned societies earlier than in Britain. In Paris in the 1870 members of the Sociéte de Anthropologie recognising 'some confusion in the uses of the terms anthropology, ethnology, and ethnography' met to discuss the issue (see also Topinard 1878:7-9). They were led by a certain M. Hovelacque who suggested that 'ethnography is not a department of ethnology, but a distinct study'. He claimed that the term ethnos signified 'race and people' while '-graphy' denoted a 'description' and '-ology points rather to a general study.' 'Geography', he argued was 'a description of the earth; geology the science of the earth.5 In summing up the discussion the leading French anthropologist P. Broca presented a sum- 
mary of the historical 'distinction between anthropology and ethnology as employed in England' and to which he apparently gave his approval:

First, there is the general study of man or of the entire human species (le genre humain tout entire); this is anthropology. Then comes the study of the natural divisions of the group, which are generally known as the races of man; this is ethnology. Finally, there is the artificial subdivision of races into peoples; this is the most special of the three branches of study, and it is to this branch we should restrict the term ethnography. (Reported in 'Science Notes: Anthropology'. The Academy, 11, 24 March 1877:255).

In Britain, however, the usual term for descriptive accounts that constituted the major source of information on the customs and organisation of other cultures was 'ethnography', although occasionally 'anthropography' was suggested as an alternative. As early as 1834, the Penny Cyclopedia (II, 97) had suggested that a 'series of anthropographies of different epochs would form the basis of ethnography' (cited in OED). The term 'anthropography' continued to make an appearance during the late nineteenth and early twentieth century, most notably in the works of the zoologist and pioneer British anthropologist, A. C. Haddon. Haddon wrote a number of works in which he attempted to classify, distinguish and define the various subfields of anthropology in an effort to promote its professionalisation in academia and beyond (Urry 1993). In his Presidential Address to the Anthropological Institute in 1903 he used the term 'Anthropography' as an alternative to Physical Anthropology, defining it as the 'lowermost plane' in a hierarchy of concerns of which 'psychology' was the highest. In between came 'ethnology' which dealt with man as 'a cultural (socius)' in contrast to a 'natural ... (anthropos or homo)' being. Haddon wrote:

Anthropography deals with man solely as an animal; Ethnology, or Sociology, studies all the enterprises of social man. Psychology takes us into the inner sanctuary of man, and while it, too, has its roots in his animal nature, it flowers, so to speak, in a realm of its own (1903: 13).

Ethnography was a 'description of a single group of man (ethnos) ... and should be a monographic study including alike Anthropography, Ethnology (Sociology), and Psychology' (1903:12) Although Haddon resorted to both Greek and Latin in his discussion, of these terms he appears not to have been concerned about the difference between 'graphy' and 'ology' 
Haddon's schema did not find much favour and in his small book on the history of anthropology, published in 1910, he used the system that the Board of Studies in Anthropology of the University of London had adopted as a guide for the study and teaching of Anthropology' (1910:4). ${ }^{7}$ Here, anthropology was divided into two broad categories, 'Physical Anthropology (Anthropography, Anthropology of some writers)' and 'Cultural Anthropology (Ethnology of some writers).' This basic division, however, had the 'ethnological' as a subcategory in both divisions. In physical anthropology, ethnological studies involved the 'comparative study of physical characters' distinguishing 'races and sub-races' - classification of race in terms of 'physical and psychical characters' and geographical distribution of 'types' along with the influences of environment. Cultural anthropology involved a consideration of 'cultural conditions and characteristics' as well as environmental influences on culture, but there was no mention of psychology or for that matter ethnographic issues connected to research and/or the writing of texts (1910:4-5). The term 'anthropology' therefore now encompassed both studies of biology and of custom with ethnology being subordinated to its usage. ${ }^{8}$

After the First World War the term 'anthropography' appears to disappear from general usage although Fallaise (1920:180) suggested the term be used for descriptive accounts of the physical aspects of 'Man as an Organism' in contrast to the 'Distribution of Man in Space' which required 'detailed Ethnology' in the form of 'Ethnography'. The latter, he suggested, involved 'the description and classification of differentiated types in specific geographic areas. Whatever the use of terms, it is clear that ethnography was to serve both anthropology and ethnology by supplying the basic factual material required for a proper understanding mankind.

ETHNOGRAPHY AND THE RISE OF METHODOLOGICAL EXPERTISE IN BRITISH ANTHROPOLOGY

During the nineteenth century the self-styled anthropologists and ethnologists in Britain who wrote on 'man and his customs' were dependent on others to supply them with the material they required to speculate on aspects of savage life, custom and the history of humankind. As anthropologists, they were mainly not the collectors of the descriptive sources which gradually became known as 'ethnography'. The collectors of this information were not, however, commonly referred to as 'ethnographers'. This is partially because all sources of information on other peoples were seen as relevant in the construction of anthropological and ethnological knowledge. These included the classical writings of the ancients, the accounts of explorers, soldiers and missionaries 
who had followed European expansion since the sixteenth century and the more recent reports by often educated government officials and settlers as European empire and colonisation expanded during the nineteenth century. But the experts at home were not uncritical of the quality of the material they had to work with and were eager to improve details on savage life. This can be seen in the production of questionnaires to solicit better information and also in numerous statements that bemoaned the poverty of existing sources, questioned its quality and praised particular reports for their detail and accuracy (Urry 1993; Stocking 2001a).

In later accounts of the development of anthropology the 'experts' at home who exploited these diverse sources were often disparaged by being referred to as 'armchair experts.' The picture conjured up by this phrase is one of an intellectual who refuses to move from their comfortable metropolitan study and who is happy to depend on others for information they could not verify and about which they are unconcerned. Such armchair experts were contrasted with men (and occasionally women) who had real experience of 'savage folk' in the 'field'. This term 'field' increasingly meant not just 'abroad', but also drew on ideas from the natural sciences where enthusiastic amateurs were increasingly joined by trained scientists in the observation and collection of facts and specimens. By the end of the nineteenth century the term was associated with a new type of expert trained in scientific methodologies for the accurate collection of material and its interpretation and analysis.

During the nineteenth century teams of scientific researchers, sometimes on naval or other expeditions, collected data and specimens and conducted regional surveys. 'Surveying' was also an important part of nineteenth century colonial expansion and included geographical surveys in order to establish settlement sites, the discovery of mineral and other resources and collection of information on the populations who had come under European control. In post-Mutiny India the British began large scale surveys of the population, eventually formalised into an 'Ethnographic Survey of India.' As its director, Sir Herbert Risley later pointed out in his Presidential Address to the Royal Anthropological Institute, the Survey involved 'the systematic description of the history, structure, traditions, religions, and social usages of the various races, tribes, and castes' (1910:16). Physical anthropological research was also included under the rubric of 'ethnography'. In the 189 os Haddon attempted a large scale 'Ethnographic Survey of the United Kingdom' where 'ethnography' meant the collection of 'facts' on culture, folklore and physical attributes of the population (see Urry 1993). 
After 1900, however, a distinction began to be drawn between 'survey' work and 'intensive' research, the latter being more focussed on a particular group, conducted for a longer period of time than was usual on expeditions and usually by a single researcher or pair of researchers. Before 1914, it was W.H.R. Rivers, a member of the famous Cambridge Expedition to Torres Strait of 1899, who most strongly emphasised this distinction. As an experienced laboratory scientist used to combining method and theory in his experimental research, Rivers was keenly aware of the need for the careful application of method to the testing of hypotheses. His first independent fieldwork involved 'testing' the value of the genealogical method he had formulated in Torres Strait among the Toda of southern India and this resulted in an ethnographic monograph. Later, his research in the Solomons with A.C. Hocart expanded this method and resulted in a number of ethnographic papers. Finally, shortly before the First World War, Rivers undertook an ethnographic survey in Melanesia in order to test certain ethnological hypotheses that he had become interested in and which were concerned with social and cultural diffusion.

During this period, so-called field research was described as 'ethnographic' and occasionally as 'ethnological' suggesting a rather loose usage of the terms was still commonplace. 'Ethnographic' research was linked to resulting published forms in articles or books while 'ethnological' seemed more connected to the theoretical issues involved in the research. Use of the term 'ethnographer' appears to have been more limited and general terms such as 'anthropologist' and 'ethnologist' were applied increasingly to university educated experts who may or may not have been involved in direct field research. After 1900, all the terms were increasingly applied to professional academics rather than to amateurs on the principle that research required some kind of academic training and explanation needed an awareness of theoretical issues acquired through scholarly study. But at this period anthropology and ethnology were only just being recognised as academic subjects in British universities, usually because the Government had at long last begun to accept the subject's usefulness for imperial control (Urry 1993).

THE BOASIAN VISION OF THE INTER-RELATIONSHIP

BETWEEN ETHNOGRAPHY AND ETHNOLOGY

Anthropology in the United States of America was 'professionalised' much earlier than in Britain. This occurred, however, not in the context of an expanding overseas empire but instead as a response to the internal expansion of settlement within the continent. The focus on gathering information on the indigenous inhabitants was initially driven by similar concerns with control 
and administration as occurred later in British anthropology with regard to the British Empire. As the Indian threat waned and new settlers swamped the country, anthropology became more concerned with antiquarian issues such as the origin of the 'Indians', their inter-relationships often associated with material culture studies based in museums rather than immediate social and political forms of peoples beyond the frontier. In the United States the federal government had supported research on the native Indians and thus supported the development of ethnology and anthropology. Much of this research, done by both officials, missionaries and 'experts' in contact with native people, was published by the Bureau of Ethnology in Washington and its large, plush volumes were the envy of many European anthropologists, including Haddon (1902).

It is perhaps not surprising, therefore, to discover that the proposals of American anthropologist, Daniel Brinton, for the divisions of the subject appeared in Haddon's first major book on anthropology. Brinton had suggested that 'ethnography', defined as 'Geographic and Descriptive Anthropology', constituted with Somatology, Ethnology and Archaeology, one of the four sub-divisions of a scientific classification of the 'Anthropological Sciences' (Brinton in Haddon 1898: 491-94). Brinton's more detailed division of ethnography into 'General' and Special', however, reveal that he conceived of ethnography not in a modern sense as descriptive accounts of particular cultures and societies, but as concerning racial classifications, origins, geographical distributions and the history of specific 'racial' groups (in Haddon 1898: 493). At this period Haddon obviously agreed with Brinton.

It was, however, the German-born and academically-trained Franz Boas who would make the greatest contributions to American anthropology after 1900. These included contributions to research methods, practical and epistemological, in areas as diverse as linguistics, physical anthropology, statistics and the study of culture (see Stocking 1968). Boas used the term ethnography in a number of ways, but most often in relation to descriptive accounts of peoples and cultures. As part of their rigorous training his students had to study existing accounts, not as a means of acquiring research techniques, but as part of their general education in anthropology (see Boas 1982 [1902]:291). As one of Boas' students later expressed it, an understanding of ethnographic diversity gained through a reading of a wide number of ethnographical studies was essential in the building of a 'science of culture.' He insisted that the study of ethnography 'must identify and correlate' aspects of 'social tradition' with others ' whether or not that lies within the same culture or outside' and not be 'limited to the study of so many integrated wholes, the single cultures' (Lowie 
1937: 235, his emphasis). ${ }^{10}$

Boas, however, argued that ethnology, as the area most concerned with the study of culture, needed a sound information base. In his early formulations he stressed the importance of collecting a proper documentary record of other cultures. Ethnography had to produce material in text form of such a high standard that it would serve not just the needs of the person collecting the material, but also future generations of scholars. Only in this manner would future ethnologists be able to understand the history of humankind with objectivity and without prejudice. This view was informed by the idea that all sound historical work was founded on written records and as most of the people ethnologists dealt with were non-literate and so lacked written records, it was the duty of ethnologists to encourage the production of source material of a quality that would sustain future critical studies. Ideally, the material was to be recorded in the native language and this could only be achieved by either an ethnologist trained in linguistics and text transcription and/or natives who had acquired literacy and who could be instructed to do the work under supervision. Moreover, it was imperative that this be done with a sense of urgency, at least in North America where the native people appeared to be losing their cultures and languages in the face of settler expansion. Of course, Boas also wanted more than just texts to be collected by his researchers; examples of material culture and art, accounts of ritual, social life and other customs were all necessary, although such sources also had to be properly contextualised with texts if the ethnological enterprise was to stand the test of time. At the heart of all this work was the recognition of the central importance of language, essential in order to understand the 'mind' of the members of other cultures. For Boas, explanations of human history (ethnology) and of the nature of humankind (anthropology) could only occur once a satisfactory and sound information base had been established.

As Stocking has pointed out, Boas' position on what might be termed the ethnographic base for ethnology - and ultimately anthropology - altered during his lifetime. More specifically, Stocking notes 'a subtle shift' during the first decade of the twentieth century 'from an 'object-oriented' to a 'textual' to a more 'participant' ethnography' (Stocking 2001b:73). Although the term 'participant' here might be seen as an appropriation of a term used later by British anthropologists to characterise their ethnographic research, one might suggest that Boas' shifting position was in part a reaction to the work of the first generation of researchers he trained and sent to gather information rather than to external influences. This first generation of Boasians, which included such figures of later eminence as Kroeber, Lowie, Radin and Sapir, all took rather 
different positions on the nature of ethnography and its relationship to the anthropological endeavour.

The opinion of one mature Boasian, A. L. Kroeber, can be seen in his essay 'What ethnography is' (1957). For Kroeber, the purpose of ethnography was ultimately to contribute to 'a reconstruction of the larger and long range movements or developments in global human culture' (1957:193). This involved both ethnology and archaeology but it did not mean ethnography was just a form of history. Indeed, Kroeber contrasted history with ethnography:

History $[i s]$... that branch of learning which deals with written documents about those actions of men which are also social events or result from general conditions. Ethnography, on the other hand, does not find its documents; it makes them by direct experience of living or by interview, question, and record. It aims to grasp and portray sociocultural conditions ... The result is that ethnography primarily portrays conditions of a moment, or culture seen synchronically, as a people's culture is organised into more or less coherent patterns (1957:192).

Kroeber suggested the limitations of the essentially synchronic nature of ethnography could be 'transcended in two ways: microscopically and telescopically'. By 'microscopically' Kroeber meant looking closely at local variations through the practices of individuals permitting the anthropologist to see local processes in action in relation to the established patterns of life - today this distinction might be termed 'structure and agency' The reference to a 'telescopic' view indicated that the anthropologist needed to widen their horizons away from a particular culture to conceive of ethnography in the contexts of time and space by including references to other cultures through comparison 'with an emphasis both on exact feature of pattern ('typology') and on occurrence in geography ('distribution')' (1957:193). The ultimate aim was to achieve 'a degree of long-range historical reconstruction ... for specific items of culture.' The aim of ethnography was, therefore, still to assist ethnology; it was not an end in itself.

MALINOWSKI, FIELDWORK AND ETHNOGRAPHIC METHODOLOGY IN BRITISH ANTHROPOLOGY

While for the Boasians ethnology and ethnography, as description and as text, remained closely linked, in Britain and its colonial dependencies the relationship changed. Here, the connection between ethnography and fieldwork 
methods - already apparent before 1914 - culminated after the First World War in a reorientation of anthropological practice and eventually of the very vision of anthropology itself. The major source of change, directly and indirectly, was Bronislaw Malinowski. This occurred through his teaching and by the ethnographic example he set in own his research and writing (Young 2004). Most of the subsequent generation of anthropologists who would come to dominate British anthropology into the 1970 s passed through Malinowski's seminars at the London School of Economics along with a number of American anthropologists. These recruits to anthropology, usually from other discipline areas, all accepted that the study of 'primitive' social and cultural life required a period of individual, intensive ethnographic fieldwork which would result in detailed ethnographic reports on a particular society.

While later generations would argue that Malinowski had created a new discipline, 'social anthropology' out of 'ethnography', in fact Malinowski was less concerned with creating a new discipline than a new practice. ${ }^{11}$ Although he used the term 'social anthropology', he more often referred to anthropology as 'cultural anthropology' and at first even as 'ethnology'. More surprisingly, as a person who has been closely associated with 'inventing' ethnography as a fieldwork methodology connected with participant observation, and as an author whose name has come to be identified as a pioneer of innovative, focused and creative ethnographic description, Malinowski does not appear to have much used the term 'ethnography'. Anthropology for him was a continuous project of personal field research through participation in the everyday life of the people studied, learning the native language and on to analysis and explanation. All this was grounded in an ethnographic particularism that for Malinowski was built on detailed descriptions of his beloved Trobrianders who were made to play a dual role as exotic South Sea savages and as examples of Everyman, exemplars of a universal humanity. As Lowie was to comment, after having immersed himself in 'the native scene ... [Malinowski became] dominated by it, and his theoretical tenets largely emanate[d] from direct observation' (1937:232).

Under Malinowski's influence, the meaning of ethnography shifted during the 1920 and 1930 s away from general descriptive accounts towards a distinctive ethnographic methodology centred on an individual researcher acting as the ethnographer who would eventually become an anthropologist, but only after a long period of sustained research. For him, and most of his followers, 'ethnography' was primarily a methodological innovation that resulted in a text that was seen as merely the end-product of a process founded in fieldwork. Ethnography was therefore something that anthropologists primarily 
did 'in the field'; ethnographic fieldwork was 'written-up' after the research was completed as the ethnographer began to build towards becoming an anthropologist. This pattern was not restricted to British anthropology but was soon extended to other anthropological traditions. For instance, a degree of convergence emerged between the ethnographic practices of British and American anthropology before World War Two. Margaret Mead, one of Boas later students, clearly identified with the idea that ethnography was based on field research using established and innovative methods but at the heart of which was participant observation focussed on specific ethnographic issues. ${ }^{12}$ She claimed her approach brought better results than those previously used by American anthropologists, a comment that drew the ire of many senior Boasians. ${ }^{13}$

By the 1940 and 50 in Anglo-American anthropology, ethnographic field research had become generally accepted as an essential stage in the process by which professional status was achieved in socio-cultural anthropology. However, if ethnographic research produced an ethnographer and an ethnographer became an anthropologist, new questions arose about the relationship between ethnography and anthropology. The assumption was that the ethnographic process, beginning in field research, produced ethnographic material that through the process of transformation into text functioned to structure anthropological explanations. But how could material produced by a methodology founded on claims to objective empiricism subsequently be translated into anthropological works of theoretical significance and remain free of theoretical influence? It was obvious that the design of ethnographic research and the structuring of description were imbued with anthropological significance before the ethnographic process had begun. Another issue was how ethnographic details, so closely tied to the interpretation of a particular society could produce explanations capable of generalisation necessary to produce ideas of comparative anthropological value? What exactly was the relationship between the ethnographic enterprise, so minutely focussed, and the larger anthropological enterprise?

ETHNOGRAPHIC METHOD, TEXT AND ANTHROPOLOGICAL THEORY:

PUZZLES AND CONTRADICTIONS

In both British and American anthropology, the practice of ethnography, although initially somewhat differently articulated, was founded on claims to empiricism. It was assumed there were pure, objective facts to be discovered through research and conveyed through the writing of descriptive texts. The Boasian assumption was that native texts, recorded in the native language, 
would lay the foundations for all future anthropological interpretation, explanation and generalisation. In time, it was hoped that through a strict adherence to proper methods of collection, collation and comparison a proper science of humankind would be established. The term 'method' for the Boasians was not, therefore, restricted merely to techniques of ethnographic collection, but instead covered the informed, intellectual engagement by the anthropologist with the source material and theoretical analysis. However, fact and theory should remain strictly separated in the collation of texts as ethnographic facts; once established according to scientific principles, these had a more permanent and lasting significance than speculative theorizing. The frameworks of explanation and generalisation were eventually to be tested, retested and revised through the reconsideration of the old sources and the addition of new evidence. In this regard, Radin, a Boasian, bemoaned the 'frequent failure to distinguish carefully between the record as obtained and the discussion of it ... [that] constitutes one of the most glaring and inexcusable defects of the majority of all monographs on aboriginal people' (1933:115). Radin specifically criticised the ethnographic work of Malinowski and Margaret Mead and their claims to better theories based upon their special field research methods $(1933: 115-16){ }^{14}$

Malinowski could be annoyingly inconsistent in his statements on the relationship between ethnographic fact and anthropological argument. For instance, he wrote that:

[The] modern specialist field-worker soon recognises that in order to see the facts of savage life, it is necessary to understand the nature of the cultural process. Description cannot be separated from explanation, since in the words of a great physicist, 'explanation is nothing but condensed description.' Every observer should ruthlessly banish from his work conjecture, preconceived assumptions and hypothetical schemes, but not theory. ....Modern field-work ... regards a theory as purely empirical, never to be taken beyond the limits of induction set by the evidence, and as serving only to give a greater insight into the mechanism of culture in its various phases; social organisation, belief and material outfit (Malinowski 1929: 864; his emphasis).

Elsewhere, he railed against 'fact worshiping, theory-dreading curio-hunting' anthropologists, while in the next paragraph he would accuse others of mixing 'abstract descriptions of a theoretical nature' with statements of 'solid fact' (1932: xxix; xxx). In a much-quoted passage, Malinowski demanded that every 
'observer should ruthlessly banish from his work conjecture, preconceived assumptions and hypothetical schemes, but not theory' (1926:132). But was scientific theory not built upon hypotheses that necessarily involved conjecture as well as preconceived assumptions and schemata? How exactly Malinowski conceived of 'theory' beyond localised explanations of specific ethnographic material is unclear as for him everything was intimately interconnected with his own particularistic and personal ethnography of the Trobriand Islanders.

Radcliffe-Brown's arguments were clearer and more forthright: ethnographic research had to be lead by theory and therefore the training of ethnographers in anthropological theory prior to undertaking field research was essential. He wrote that:

The conception of the newer anthropology ... is that only the fieldworker, the one actually in contact with the people, can discover the meaning of the various elements of the culture, and that it is necessary for him to do this if he is to provide material to be fully utilised for the purposes of science.... The field-worker of the future, or indeed of the present, must be thoroughly cognisant of all the sociological hypotheses that are partly verified, and if possible of those in course of elaboration, and must direct his research to the testing of these hypotheses, either his own or those of other workers in the science, by their application to a particular culture. Only in this way can the hypotheses be tested and either verified, rejected, or modified .... Only so can the proper method of the generalising sciences be carried out, namely, the process of making a preliminary study of known facts, the formulation of hypotheses by a further examination of a series of data, the modification of original hypotheses in the light of the new data, the further testing of the hypotheses in their new and possibly more complex or more definite form, and so on. Only in some such way as this, in default of the possibility of actual experiment, can we build up a science of human society. (RadcliffeBrown 1958 [originally 1931]: 67, 71).

For Radcliffe-Brown, the 'science of human society' went by a number of names besides social anthropology. During the 1930s, Radcliffe-Brown and those who at the time attached their colours to his mast used the term 'comparative sociology' for their new field of study (Radcliffe-Brown 1958 [1931]; Firth 1937; Evans-Pritchard 1937). Indeed, for a brief period it seemed that those who had become ethnographers in the Malinowskian mode might abandon anthropology entirely for sociology. At the time, the older anthropologist, 
A. M. Hocart, commented that Radcliffe-Brown identified 'anthropology with sociology, which studies not the evolution of society, but the laws that govern its behaviour' (1933:1-2). He then asked, but 'why take from the evolution of man the title of anthropology, leave it without a name, and bestow that title on the duplicate of a science which already has one, namely sociology?'

Following the Second World War, the American anthropologist George P. Murdock (1952) echoed Hocart when he accused British anthropologists of being sociologists not anthropologists. By this time, most British anthropologists had followed Radcliffe-Brown and abandoned 'comparative sociology' in favour of the term 'social anthropology' to describe their discipline. The adoption of the term 'social anthropology' had been strategic for Radcliffe-Brown; 'anthropology' was the general term for the 'science' of man and reflected his desire to raise social anthropology to the status of other scientific enterprises such as biology and chemistry from which he drew many analogies in his theoretical models. By adding the prefix 'social' to 'anthropology' he was signalling his desire to establish a 'natural science' of society informed by inductive scientific methods and theory which he interpreted as an ability to formulate law-like statements.

The attack on Radcliffe-Brown's claims would come in the 1950 from one of his earlier supporters, E. E. Evans-Pritchard, who identified social systems as moral, not natural systems; anthropology as a field of study was more closely linked to historiography and the humanities than to the natural sciences. $\mathrm{He}$ argued that social anthropology involved descriptive integration but noted that anthropological syntheses involved greater abstraction and generalisation than in history (1951: 61). Evans-Pritchard clearly connected his comments to those of Kroeber, more explicitly to Kroeber's attack on Boas in which Kroeber had accused Boas of not understanding that history required 'descriptive integration' and not the type of scientific analysis that involved the division of the material under study (1935). ${ }^{15}$ But Evans-Pritchard, while willing to abandon the functionalism of Malinowski and the natural science models of Radcliffe-Brown, wished to retain as the title of his subject 'social anthropology'. Ethnography was to remain the entry point for practitioners to the discipline and, in spite of his claims to the importance of historiography, he too wanted little to do with the old ethnology. Instead he stressed the need to identify the 'underlying structural order' of a society studied ethnographically and then to advance to comparative studies in order to establish common 'structural patterns' across societies (1950: 61-62).

In an extensive and acerbic review of Evans-Pritchard's book, Radcliffe Brown 
pointed out the implicit contradictions contained in Evans-Pritchard's claims. It was clear, he suggested, that when Evans-Pritchard stated that anthropology was a kind of historiography

he means that a sociographic account of a particular society can be similar in important respects whether it is provided by a historiographer from studies of records and monuments or by an ethnographer from personal observation and the statements of informants. No one is likely to disagree with this and indeed it is so obvious that it certainly does not need to be stressed. Where there will be disagreement is with the implication that social anthropology consists entirely or even largely of these ethnographic studies of particular societies. It is towards some such position that Professor EvansPritchard and a few others seem to be moving (1951:365).

Radcliffe-Brown recognised that a trend was emerging focussed more on ethnography than comparative analysis. He reasserted his view that while anthropology 'must begin with studies of particular societies, which we can call sociography as including ethnography and historiography' this only provided 'the data for systematic comparative studies' that would lead eventually to the formulation of more general theories about human societies (1951:365-66).

THE DEMISE OF ETHNOLOGY IN BRITISH AND AMERICAN ANTHROPOLOGY

Haddon preferred to call himself an ethnologist rather than an anthropologist. In the years between the two World Wars, however, he witnessed the rapid demise of ethnology and the historical dimension associated with its name. His recognition of these changes can be seen in the revised version of his History of Anthropology, first published in 1910 (Haddon 1934). In the new preface he replaced the complex outline of the subject of anthropology, agreed upon in 1909 by the University of London Board of Anthropology, with a simpler scheme that recognised just three major fields in anthropology: 'Human Biology', 'Cultural Anthropology (Ethnology of some writers)' and 'Ethnography' (1934: vi-vii). Within the first two fields Haddon identified a number of sub-divisions including, under cultural anthropology, the description of the structure and function of individual and group elements in social culture and of the cultures themselves' (1934: vii). Ethnography he described simply as the intensive study and description of a particular group or area dealing with all the above', with the suggestion that ethnography could serve both Human Biology and Cultural Anthropology. Elsewhere in the book, he spoke of ethnographic accounts 'of actual field-work' which he identified as just one form 
of 'ethnological publication' (1934:124), but he went on to criticise modern ethnographic accounts where the

method of treatment of ethnographical studies is undergoing a change. Usually the data of economic, social and religious life have been described as almost independent phenomena, with the result that they presented static pictures, which, even when combined, were insufficient to form a true panorama of life, and they did not sufficiently present those interacting activities and motives that alone can give rise to a satisfying conception of a living society (1934:124).

Certainly, intensive field research had important consequences for ethnography as well as its relationship with ethnology and anthropology in general. The research, so focused on a particular, localised society meant that any description of the society that resulted was inevitably severely circumscribed in time and space unless the ethnographer had access to other sources beyond their direct experience. Of course, the ethnographer could ask informants about the past and many did, their insistence that they studied 'living' societies included a denial that they were interested in 'salvage' ethnography like earlier anthropologists and contemporary Boasians. Malinowski in his ethnographic accounts, however, largely disregarded external influences such the colonial situation, the presence of missionaries, labour contracts and the impact that disease and population decline had brought about through contacts with outsiders. In spite of the rhetoric that the new ethnographers studied real life in the here-and-now, the actual research resulted in a tendency to 'reconstruct' 'traditional' ways of life. Such accounts could be an end in themselves or they could be used - as in studies of 'social change' or 'culture contact' ('acculturation' in American studies) - to provide a base line from which to assess the impact of the radical changes contact that European expansion and colonisation had wrought on their ethnographic subjects.

One unfortunate effect of this was to create an impression that, prior to the arrival of foreign influences, people had existed in a continuous state of isolation in which society and culture had been replicated for generation after generation. Such a view was supported by the idea that societies and cultures were wholes - bounded, self-perpetuating social and cultural universes. This implied that outside influences were generally negative as they had upset the 'natural' cycle of social and cultural replication. Such views involved a moral judgement about 'change' in society and were in part a product of the ethnographic methodology in which the knowledge of any society was restricted 
by the limited time the ethnographer spent in the field. Ethnographers were often unwilling to accept evidence other than that which they had collected themselves and instead tended to explain everything they saw in terms of the 'ethnographic present' with its concentration on the here-and-now functioning of everyday life (see Burton 1988).

Finally, there was also an unwillingness to move beyond the ethnographer's own particular situation into comparative analysis, either regional or more general, even when comparative analysis was seen as the ultimate aim of anthropology. General comparative analysis involved relating aspects of a society to others usually separated in time and space while regional analysis was based on the idea that neighbouring groups were so connected. The exact ways in which a specific group studied ethnographically might be connected to others, especially in terms of history, was rarely investigated. ${ }^{16}$ Instead there was a general assumption that proximity resulted in similarity and this was often based on an earlier identification of an ethnological culture area, even while ethnological issues were not in themselves deemed topics worthy of further study. ${ }^{17}$

While Malinowski, more by default than strategic intent, rejected the historical emphasis associated with the older ethnology, Radcliffe-Brown set out systematically to exclude it from what he considered proper scientific anthropology (see Urry 1993). ${ }^{18}$ In a number of statements issued in various versions between the 1920 and early 50s, ethnology was associated with unscientific reasoning and in terms of method impossible to achieve through ethnographic field research. As ethnographers dealt largely with societies whose members were non-literate, there were no reliable sources of information on their past. And ethnology was essentially unscientific as it involved conjecture, not direct evidence. ${ }^{19}$ So successful was Radcliffe-Brown in getting his point across that almost an entire generation of British anthropologists would endlessly repeat his argument that 'conjectural history' was not worthy of anthropological study.

Radcliffe-Brown was successful not only in dumping ethnology and redefining scientific anthropology as social anthropology, but he also argued that a new kind of ethnography was primarily linked to this new science. He acknowledged that Haddon had 'urged that both ethnology and social anthropology ... be based on systematic ethnographic field studies carried out by trained anthropologists using scientific methods of observation' and that in Britain this had resulted in what we can call a new kind of ethnography, in which the field worker did not confine himself to simple description but sought to include in his account some sort of ethnographic analysis'. 
Without mentioning Malinowski, he noted that 'this kind of ethnography was undertaken for the purpose of providing material for the comparative studies of social anthropology rather than for the historical reconstructions of ethnology' and so 'it came to be included under the general term social anthropology' (1952:276-77).

At the Wenner-Gren Foundation's sponsored meetings in New York in 1952, the British anthropologist Daryll Forde was asked by Kroeber whether 'there was anyone doing Ethnology' in Britain and did 'anybody in England today admit to being an ethnologist, actively practicing ethnology?' Forde managed to name two people but Siegfried Nadel described Forde's efforts as 'overoptimistic', pointing out that none of the people he identified were attached to a university but instead to museums (in Tax et al 1955: 222). Social anthropology had indeed triumphed: ethnology as a field of study was effectively dead in Britain by the 1950 .

In the United States cultural anthropology grew directly out of ethnology which had long emphasised the history of culture. As the Boasians banished grand evolutionary models from anthropology so interest in biological issues declined and links with archaeology weakened. Although the American anthropologists who championed 'cultural' anthropology after the Second World War were critical of the narrow focus of British social anthropology, they acknowledged the high standard of its ethnography and attributed this to a strong tradition of research founded on participant observation informed by 'theory' (Mead 1952, Murdock 1952, Lowie 1953) ${ }^{20}$ By the 1950 os Lowie declared himself happy to be called an 'ethnographer or cultural historian' who, while interested in social factors, was unlike British anthropologists in that he also wanted to know the 'distribution in time and space - what, where, and when' of social phenomena - a classic ethnological concern. He noted that like the British he too could 'crave' generalisations, but he did so only 'so far as they are demonstrable ... above the level of platitudes'. Finally, he declared that he was concerned with 'culture, the whole of it, intransigently and impenitently' (Lowie in Tax et al 1953:223). Even Kroeber would now question the value of ethnology, ruminating after the Second World War that he was perhaps now willing 'to abandon this baby to the wolves' (Kroeber 1953:366-67; see also Eggan 1954:756). Cultural anthropology was in; ethnology, as it had long been conceived, was in retreat.

In the wake of the Second World War, as the United States became a global power, American anthropologists expanded out of their established ethnographic base in North America often assisted directly or indirectly by gov- 
ernment grants. As in Britain, the new emphasis on field research led to an increased emphasis on ethnography as a methodology and the anthropologist, in the first instance, as an ethnographer. Howard Conklin's entry on ethnography in the 1968 International Encyclopedia of the Social Sciences stressed that it was a method but said less about it as a mode of description. As in Britain, the historical emphasis of the old ethnology was replaced by here-and-now ethnographic accounts of particular cultures. Unlike in Britain, however, the historical dimension was given a new name - ethnohistory - although those working in the field tended to be more restricted to studies of the North American continent and drifted towards 'contact' history (see Fenton 1952 for an indication of this change). As with British social anthropology, the emphasis on ethnography both as a means and product of field research in American cultural anthropology, resulted in a marked narrowing of focus. In America, the broader vision of Anthropology was preserved in the structure of many academic departments and in the older journals by dividing the discipline into 'four fields': cultural anthropology, physical anthropology, archaeology and linguistics. ${ }^{21}$

In British universities, linguistics and archaeology tended to develop into separate disciplines with their own distinctive methods while physical anthropology developed mainly in the biological sciences. This left social anthropology to dominate the field. Yet even in America the four fields approach increasingly resembled one of Tylor's 'survivals' and cultural anthropologists began to dominate many university departments and their journals. In Britain, the 'social' in social anthropology was a generic term that could indicate a wide range of approaches. Its very broadness led to internal specialisations that both reflected particular methodological and theoretical interests and new ethnographic methodologies. Anthropology could now be 'economic anthropology', 'political anthropology' with specialist economic/ political anthropologists but always within the rubric 'social' (see MacDonald 2001 on the shifting fields and identifications by anthropologists). In terms of being ethnographers, however, anthropologists remained generalists: terms such as 'economic ethnographer' or 'political ethnographer' were never used. For some, however, the methods of ethnographic research did become more specialised. Max Gluckman developed a more radical approach to the here-and-now of participant observation through the study of social situations and case studies (see Gluckman 1961 and the collection of essays by his students, Epstein 1967). At the other end of the spectrum, younger scholars began to feel that the emphasis on the 'social' restricted their studies in a field where a range of customs had either been relegated to marginal positions or were to be analysed just as sociological phenomenon. The gradual adoption of the broader American focus on 'culture' 
seemed liberating, as did the rediscovery of old ideas, particularly from France. This was often discussed as a shift from 'structure and function' to 'meaning' and the emphasis on culture certainly increased interest in the study of the cultural representations held by the people studied rather than on the explanations of social form and function identified by observer.

Increasing criticism of the poverty of explanatory approaches in British anthropology often pointed to the domination of ethnography-as-method and the highly localised nature of ethnographies at the expense of more general anthropological explanation and generalisations. Jarvie (1964) identified some of the problems, but his ideas for reform threatened to return anthropology to the dark ages of a Frazerian anthropology. Evans-Pritchard's earlier criticisms of Radcliffe-Brown and his suggestion that anthropology might be better conceived of as a form of historiography, raised a number issues including what was to be compared in any 'comparative' social anthropology. ${ }^{22}$ But instead of focussing discussions on problems of explanation, his criticisms raised new questions about the quality of ethnographic accounts in terms of interpretation. His approach focussed on epistemological issues associated with translation and in their most philosophical forms his criticisms lead to a position where for some ethnography-as-method seemed impossible. ${ }^{23}$ However, the interest in translation did raise new questions on the role of language, meaning and modes of expression. The time had come for the return of ethnography as text with all its problems which are too numerous to discuss in the space of this paper (see Geertz 1977; 1988; Clifford 1983; Marcus and Cushman 1982; Clifford and Marcus eds 1986 and discussions by Spencer 2001; see also Sangren 1988, Spencer 1989; Strathern 1987; Nicholas 1991 etc.)

\section{FRENCH VIEWS: THE CONTINUED INTEGRATION OF}

\section{ETHNOGRAPHY, ETHNOLOGY AND ANTHROPOLOGY}

At the Wenner-Gren meetings in New York, in 1952, a number of participants from outside the Anglo-American world of anthropology discussed their different understandings of anthropology as a field of study. Claude Lévi-Strauss noted that in France the term anthropology was 'limited to physical anthropology', ethnography indicated 'descriptive and geographical' studies and ethnology was 'a systematisation' using 'mostly the historical approach' (in Tax 1953: 221) ${ }^{24}$ In later years, Lévi-Strauss made a number of comments on the relationship between ethnography, ethnology and anthropology. He drew less on French ethnological traditions that dated back to the nineteenth century and more on the sociological traditions stemming from Émile Durkheim and Marcel Mauss. In the early years of the twentieth century, Durkheim had made 
extensive use of ethnographic reports and had encouraged his disciples of the L'Année Sociologique to do likewise; Mauss had encouraged ethnographic research in the 1920s. But Lévi-Strauss also drew on Anglo-American traditions, particularly those of Boas and his students. In terms of ethnography he acknowledged the importance of Boas's ethnographic analysis 'which is incomparably more honest, solid and methodical than that of Malinowski' (1963a: 20). Like Kroeber (1935), however, he criticised Boas for his lack of integration in American anthropology.

For Lévi-Strauss, ethnography was the first stage in anthropological research and involved 'observation and description' based primarily on field research that focused on a single community (1963a; 1963b:354-55). He suggested that ethnology's 'relation to ethnography' was that ethnography involved merely a first step 'toward [a] synthesis' that, '[w] ithout excluding direct observation [,] ... leads towards conclusions sufficiently comprehensive to preclude, or almost to preclude, their being based solely on first-hand information' (1963b:355). Such a synthesis, in other words, lay beyond ethnography and included 'geographical' considerations involving a consideration of neighbouring groups, 'historical' reconstructions of the pasts of one or several groups and 'sociological' analyses based on ethnography and other forms of evidence. Such an ethnological synthesis would, in turn, lead ultimately to a higher synthesis, to an 'anthropology' free from the terms limited association with just physical anthropology and instead concerned with:

a global knowledge of man - embracing the subject in its full historical and geographical extension, seeking knowledge applicable to the whole of human evolution ... valid for all human societies from the large modern city to the smallest Melanesian tribe' (1963b:355-56).

For Lévi-Strauss, Ethnography, ethnology, and anthropology do not form three different disciplines, or three different conceptions of the same branch of study. They are instead three stages, or three moments of time, in the same line of investigation, and preference for one or another of these only means that attention is concentrated on one type of research, which can never exclude the other two (1963b: 356$){ }^{25}$

In 1992, the French anthropologist Philippe Descola suggested in an interview that French and British anthropologists had very different conceptions of the meaning of 'anthropology'. Acknowledging the influence of Lévi-Strauss, Descola suggested that anthropology was just an 'element' in a sequence, both scientific and personal that: 
starts with ethnography, goes on to ethnology, and ends in anthropology. Ethnography is basically the collection of data, ethnology the analysis of those data in a comparative framework in which models are constructed, and anthropology - which is a project more than a science - takes up the old philosophical anthropology of making sense of general problems in social life such as cultural variability etc. (Descola in Knight and Rival 1992: 9).

Descola noted that it was 'rare' for people to undertake anthropology but that Lévi-Strauss was one of the few people who did 'real anthropology in that sense.'

Descola went on to explain that ethnography - ethnology - anthropology involved a sequence of increasing maturity in the development of an anthropologist. He argued that 'in the career of an anthropologist, one starts by doing ethnography, and then ethnology, and perhaps some end up doing anthropology'. Descola was keen to stress, however, that this 'sequence is not ... a progression in dignity; it doesn't mean that ethnography is unimportant.' In British anthropology, however, he sensed 'a confusion of the three topics - ethnography, ethnology and anthropology', because the British tended to call everything they did 'anthropology' this also lead to confusion among scholars 'across the [English C] hannel.'

Descola also noted that French and the British anthropologists differed in how they conceived of the 'project of anthropology and the status of what we are doing.' The French aimed at building a 'theoretical framework based on deductive hypotheses ... grounded in cultural invariants and basic features of human nature' in order to 'explain the variability of specific phenomena in specific societies.' In contrast, the British were empiricists who worked inductively to make sense of 'specific institutions in specific societies.' What Descola suggested was that most British anthropologists were really ethnographers, tied closely to empirical detail centred on the ethnographic material collected in their fieldwork. Field research never had the same emphasis in French anthropology although, somewhat critically, Descola notes that in recent years 'a sort of religion of fieldwork' had emerged among younger French researchers who carried out 'incredibly long spells of fieldwork.'

In a more recent article, Descola has returned to this issue with some additional insights. Recognizing that a division of the discipline into ethnography, ethnology and anthropology might lead to the three stages being considered 'compartmentalised' and even 'incompatible', he suggests a 'trilogy ' of 'descrip- 
tion/comprehension/explanation' as a 'continuum that cannot be segmented easily' (2005: 68). Appealing for a more dynamic interrelationship involving a combination of the three aspects and their established methods, he recognises that while 'there is a certain likeness between these procedures and the classical three stages of anthropological research' they are really 'a purified definition of operations that are most often intertwined.'

For the ethnographic moment is descriptive, but also implies a good measure of comprehension through a partial identification with others, while the ethnological moment subordinates inductive explanation to a comprehensive approach, and if the anthropological moment theoretically falls under the jurisdiction of hypotheticodeductive explanations, it is nevertheless not independent of the previous procedures that have rendered it possible by providing autonomy and substance to certain classes of phenomena used in the building of models. That is why anthropology ... is not ... a clearly circumscribed domain of inquiry, or even a ...type of method ... It should be seen ... as a certain style of knowledge ... (2005:72 Descola’s emphasis).

Few others in recent years have presented such an embracive, integrated vision for the discipline of anthropology, or one connected with a career structure that might lead to a mature discipline. As Descola indicates, too many Anglo/British anthropologists appear to be stuck somewhere between high level ethnographic interpretation and low-level forms of explanation that remain closely tied to the apron strings of ethnography. This is the consequence of anthropology's ethnographisation.

\section{CONCLUSION}

It might be argued that this paper has a rather antiquarian flavour, concentrating too much on historical detail and issues of semantics and not enough on present needs and future directions. Indeed, it might be interpreted as an attempt to deny the role of ethnography as providing the essential base for anthropology's sense of as a discipline relevant to the modern world. I would be the first to admit that without its ties to ethnography the discipline would be impoverished. As I often tell students, all the strengths of anthropology stem from its involvement in ethnography, but so do many of its weaknesses. From ethnography being in the present but linked to the pasts of those studied, we now have an ethnography linked from the present to the future. Every institution, organisation, 'problem' and current issue 'needs' the input of an 
ethnographer and then all will be well.

Ethnographic practice not combined with strategies of making sense of humankind in both the particular and the abstract is a practice no longer in the service of anthropology. By 'the abstract' I mean that anthropology has to be more than just a means by which a set of celebrity designers exhibit their pursuit of novelty in increasingly bizarre fashion shows where extremely odd notions, scantily covered by ethnographic description, are paraded down the catwalk to the applause of would-be-devotees. Theoretical discussions have often degenerated into little more than stylistic statements of allegiance to current taste. Instead of structured arguments, we are presented with brief epigrammatic statements, usually rather vague and indecisive in form, which somehow are to be taken as profound.

As a discipline, anthropology needs a more clearly defined career structure that leads scholarship away from the essential juvenility of ethnography as a practice and form of writing into more mature fields of anthropological discussion and debate. Such mature discussions and debate require anthropologists to connect their ethnographic knowledge and not to keep it separate and selfcontained in a bubble of relativism. The points about the field of study that Lévi-Strauss and Descola raised therefore need to be considered seriously. ${ }^{26}$ The ethnographicised anthropology that developed in Anglo-American anthropology during the twentieth century, to the exclusion of a wider focus on context and ideas, needs to be both re-ethnologised and re-anthropologicised. Either way, we need to move beyond ethnography.

Personally, I would suggest that any ethnographic description has to be located, grounded, placed in time and space; it must not be seen as just an end in itself, a report of 'findings' based on a methodology or material for illustrating current fashionable ideas. In this sense ethnology and anthropology, as interconnected fields of study, need to inform and be informed by the ethnographic material collected by an ethnographer in the here-and-now while being related to the wider world. Only in this manner can a mature anthropology be built, including, but also beyond, ethnography. ${ }^{27}$

NOTES

1 The Greek suffix 'ology' or 'logy' means roughly 'the study of' with an emphasis on the scientific and the theoretical. So 'anthropology' is 'the study of humankind' (anthropos); 'ethnology' and 'ethnography' are based on ethne, 'peoples/ nations.' The 'graphy' in ethnography indicates something denoted or described, 
connected in turn to the notion of something written or inscribed (graphe). Whereas the suffix 'ology' is derived from logos, word/reason, graphos implies literacy, suggesting the existence of a text. In antiquity as the oral word was transformed into text, so graphos acquired a sense of something fixed and certain, even having the authority of law. I am grateful to Dr Matthew Trundle for discussions on these matters.

2 The term 'sociography' was used in a limited sense in Germany and in the United States of America to imply a local sociological study, usually of a survey form, and its reporting (for example Jahoda, Lazarfeld and Zeisel (1972 [orig. 1932]); I am grateful to David Pearson for first pointing this out to me. Use of the term has never really caught on and it has disappeared from many dictionaries of sociology although, as will be seen below, Radcliffe-Brown used the term along with ethnography in the early 1950 .

3 Scholars studying nineteenth century literature also use the term ethnography for the descriptive accounts of people found in fiction and non-fiction, see Herbert (1991) and Buzard \& Childers (1998).

4 Usage of terms such as ethnology and ethnography had first developed in German-speaking lands during the late eighteenth century, associated with critical thinkers of the German Enlightenment. But no special institutions devoted to the collective study of these fields developed. On German usage and its connection with later developments see Vermeulen (1995) and especially Petermann (2004) who has recently discussed the development of these terms in the context of eighteenth and nineteenth century German thought especially in section 3, part 2: Differenzierungen Anthropologie, Voelkerkunde, Ethnologie.

5 One early British source, poorly identified in nineteenth century dictionaries, suggested a similar relationship between ethnography and anthropology in that they 'bear the same relation to one another as geology and geography' (attributed to Fleming in OED).

6 Haddon in fact had struggled to pass the examinations in Latin and Greek that were required to enter university, see Quiggin (1942).

7 This was probably the outcome of discussions during 1906 on sociology as an academic subject in which Haddon participated, see Haddon (1907).

8 In order to claim a historical justification for his own views of the proper division of anthropology, Radcliffe-Brown would later suggest that the classification 
of the University of London Board had included his definition 'social anthropology', but this is incorrect (see Urry 1993:138).

9 The term appears to have come into general usage sometime in the late nineteenth century and Haddon popularised it to stress the difference between field researchers (like himself) and others.

10 Lowie made this point in a criticism of Malinowski's functionalism; Malinowski, he argued was 'avowedly antidistributional, antihistorical, and treats each culture as a closed system' (1937: 235); see also below.

11 For an example of such a claim by an anthropologist see MacDonald (2001: 60): 'At the heart of Malinowski's definition of the 'new' discipline was 'ethnography' - detailed, first hand, long-term, participant observation fieldwork written up as a monograph about a particular people.'

12 Mead was married to two anthropologists educated in the British tradition, the New Zealander Reo Fortune and Gregory Bateson and she carried out ethnographic field research with both men.

13 They could see little in her claims to innovation that they had not already done, and were also critical of her linguistic abilities and the lack of ethnographic texts (see Urry 1984). One, Paul Radin, described her as 'essentially a journalist in the best sense of the term' and suggested that her ethnographic accounts were 'simply impressionistic sketches' (1965 [1933]:170, 173).

14 Also see Radin's note 14 on the same page where he questions Malinowski's methodological claims made in the introduction to his Argonauts of the Western Pacific.

15 In fact, Evans-Pritchard misrepresents Kroeber's position as he equates Kroeber's views on the relationship of history to anthropology as supporting his own views on anthropology as a branch of the humanities; Kroeber clearly identified history as a science and anthropology as a science which along with other sciences required a historigraphic approach.

16 See, for example, Radcliffe-Brown's study of Australian social organisation (1931) and later Richards (1950) on matrilineal marriage and settlement patterns in central Africa.

17 British anthropologists who began their studies in colonial situations often 
brought with them the ethnological concerns that continued as they studied in Britain and afterwards; see for instance the work of Isaac Schapera on southern Africa (1930).

18 Malinowski was greatly aided by the presence of the extreme diffusionist Grafton Eliot Smith at University College just across town from the London School of Economics and also part of the University of London. The views of Smith and his student, W. J. Perry, who argued that culture had been invented once and spread around the world, provided an easy way for Malinowski and his students to reject ethnology in general.

19 The term 'conjectural history' Radcliffe-Brown derived from the studies of the Scots moral philosophers of the Scottish Enlightenment who used information on other cultures to reconstruct the 'history of mankind'. In their usage the term had a positive meaning.

20 The discussion of British anthropology followed Firth's account of modern British anthropology grounded in ethnographic field research (1951) and occurred in the context of a wider discussion of the present state and future direction of American anthropology.

21 It is unclear when the term 'four-fold' emerged in American anthropology but it was in common usage by the 1950s. On its historical manifestations and the myths of integration see Borofsky 2002.

22 The decline of the comparative approach occurred in both British and American anthropology as ethnographic fieldwork became the norm in both traditions. Eggan (1954) attempted to ethnologise comparison in social anthropology through his idea of 'controlled comparison.' His suggestion, however, was not followed in detail. In spite of this, most anthropologists still conceived of themselves as working in an 'ethnographic area/region' without any systematic consideration of the categories they were using (see Thomas 1987; 1997).

23 One result was the rejection of scientism in theory; ethnographic methods became less clearly defined and in the view of some, only for the better (see Grimshaw and Hall 1995; on the uses of 'scientific' approaches in ethnography as sources of power see also Asad (1994).

24 Later Lévi-Strauss suggested: 'Man can be defined in two ways: as a tool making-animal or as a social animal. If you consider him as a tool-making animal, you start with tools and go to institutions as [it is] tools which make the social 
relations possible. That is cultural anthropology. If you consider him as a social animal, you start with social relations and reach tools and culture, in the wide sense of the term, as the way in which social relations are maintained. The difference is exclusively one of point of view, and there is no deep difference between the approach of social anthropology and that of cultural anthropology' (LéviStrauss in Tax 1953:224).

25 Elsewhere, however, Lévi-Strauss noted a contradiction existed between an ethnology facing the 'problem of reconstructing a past we are incapable of grasping' and an ethnography confronting 'the problem of writing the history of a present without a past' (1963a:3).

26 Of course these authors are just two I have selected at random; their ideas could be found among other French and European anthropologists beyond the reach of Anglo-American anthropology which, unfortunately, through the propagation of ethnographic 'field work' as a methodology in and for itself, has tended to recreate the same problems elsewhere.

27 There have been a number of efforts to produce broader accounts even if they are not presented under the rubric of ethnology. Of particular note are the writings of Jack Goody (1971, 1976, 1982, 1990, 1993 just to indicate part of his oeuvre) which deal with a number of themes through comparison by contrast within wider cultural and historical frameworks. It is perhaps a reflection on the discipline that a number of these books have never been reviewed in anthropology journals. See also Kuper (1982) on an ethnological/ethnographic issue in southern Africa.

\section{REFERENCES}

Asad, T. 1994. 'Ethnographic Representation, Statistics and Modern Power', Social Research, 61:55-88.

Beattie, J. M. 1956. 'Social Anthropology', in Alan Pryce-Jones A New Outline of Modern Knowledge. London: Victor Gollancz. 1964. Other Cultures. London: Cohen \& West.

Boas, F. 1982 [1902]. 'Anthropological Instruction in Columbia University', in G. W. Stocking Jr. (ed.), A Franz Boas Reader: the Shaping of American Anthropology, 1883-1911. Chicago: Chicago University Press. 
Borofsky, R. 2002. 'The Four Subfields: Anthropologists as Mythmakers', American Anthropologist, 104 (2): 463-81.

Burton, J. W. 1988. 'Shadows at Twilight: A Note on History and the Ethnographic Present', Proceedings of the American Philosophical Society, 132: 420-33.

Buzard, J. and J. Childers (eds), 1998. 'Special Issue: Victorian Ethnographies', Victorian Studies 41(3).

Clifford, J. 1983. 'On Ethnographic Authority', Representations, 1:118-46.

Clifford, J. and G. E. Marcus (eds), 1986. Writing Culture: the Politics and Poetics of Ethnography. Berkeley: University of California Press.

Conklin, H. C. 1968. 'Ethnography', in International Encyclopedia of the Social Sciences, Volume 5:172-78. New York: Macmillan \& the Free Press.

Descola, P. 2005. 'On Anthropological Knowledge', Social Anthropology, 13: 6573.

Eggan, F. 1954. 'Social Anthropology and the Method of Controlled Comparison', American Anthropologist, 56: 743-63.

1961. 'Ethnographic Data in Social Anthropology in the United States', Sociological Review, 9:19-26.

Epstein, A. L. (ed.) 1967. The Craft of Social Anthropology. London: Tavistock.

Evans-Pritchard, E. E. 1937. 'Anthropology and the Study of Society', in J. E. Dugdale (ed.), Further Papers on the Social Sciences: their Relations in Theory and in Teaching. London: Le Play House Press.

— 1951. Social Anthropology. London: Cohen \& West.

Fallaise, E. N. 1921. 'Suggestions for the Classification of the Subject-matter in Anthropology [with subsequent discussion]', The Museums Journal, 20:14983 .

Fenton, W. 1952. 'The Training of Historical Ethnologists in America', American Anthropologist, 54:328-39. 
Firth, R. 1937. 'Anthropology and the Study of Society', in J. E. Dugdale (ed.), Further Papers on the Social Sciences: their Relations in Theory and in Teaching. London: Le Play House Press.

— 1951. Contemporary British Social Anthropology. American Anthropologist, 53:474-89.

Geertz, C 1977. The Interpretation of Cultures. New York: Basic books.

— 1988. Works and Lives: the Anthropologist as Author. Stanford: Stanford University Press.

Gluckman, M. 1961. 'Ethnographic Data in British Social Anthropology', Sociological Review, 9:5-17.

Goody, J. 1971. Technology, Tradition and the State in Africa. Oxford: Oxford University Press.

- 1976. Production and Reproduction: a Comparative Study of the Domestic Domain. Cambridge: Cambridge University Press.

— 1982. Cooking, Cuisine and Class: a Study in Comparative Sociology. Cambridge: Cambridge University Press.

1990. The Oriental, the Ancient and the Primitive: Systems of Marriage and the Family in the Pre-Industrial Societies of Eurasia. Cambridge: Cambridge University Press.

— 1993. The Culture of Flowers. Cambridge: Cambridge University Press.

Grimshaw, A. and K. Hall 1995. 'The Rise and Fall of Scientific Ethnography', in A. S. Ahmed and C. N. Shore (eds), The Future of Anthropology: its Relevance to the Contemporary World. London: Athlone Press.

Haddon, A. C. 1898. The Study of Man. London: Bliss, Sands \& Co.

- 1902. 'What the United States of America is Doing for Anthropology', Journal of the Anthropological Institute, 32: 8-24.

— 1903. 'Anthropology, its Position and Needs', Journal of the Anthropological Institute, 33:11-23. 
- 1907. [Comment] in R. M. Webley 'Sociology as an Academic Subject', Sociological Papers 3: 294-95.

1910. History of Anthropology. London: Watts.

— 1934. History of Anthropology. (2nd edition) London: Watts.

Herbert, C. 1991. Culture and Anomie: Ethnographic Imagination in the Nineteenth Century. Chicago: University of Chicago Press,

Hocart, A. M. 1933. The Progress of Man: a Short Survey of his Evolution, his Customs and his Works. London: Methuen.

Jahoda, M., P. E. Lazarfeld and H. Zeisel 1972 [orig. 1932]. Marienthal. The Sociography of an Unemployed Community. London: Tavistock.

Jarvie, I. C. 1964. The Revolution in Anthropology. London: Routledge \& Kegan Paul.

Knight, J. and L. Rival 1992. 'An Interview with Philippe Descola'. Anthropology Today, 8(2): 9-13.

Kroeber, A.L. 1935. 'History and Science in Anthropology', American Anthropologist, 37:539-69.

— 1953. 'Concluding Review', in Sol Tax et al. eds, An Appraisal of Anthropology Today. Chicago: Chicago University Press.

— 1957. 'What Ethnography is', in his Ethnographic Interpretations 1-6: 191-204. Berkeley: University of California Press. (University of California Publications in American Archaeology and Ethnology, 47)

Kuper, A. 1982. Wives for Cattle: Bridewealth and Marriage in Southern Africa. London: Routledge.

L[atham], R. G. 1855. 'Ethnology', Encyclopedia Britannica. 8th edition.

Lévi-Strauss, C. 1963a. 'Introduction: History and Anthropology', in his Structural Anthropology. London: Allen Lane.

_ 1963b. 'The Place of Anthropology in the Social Sciences and Problems 
Raised by it', in his Structural Anthropology. London: Allen Lane.

Lowie, R. H. 1937. A History of Ethnological Thought. New York: Holt, Rinehart \& Winston.

— 1953. 'Ethnography, Cultural and Social anthropology', American Anthropologist, 55:527-33.

MacDonald, S. 2001. 'British Social Anthropology', in Paul Atkinson et al. (eds), Handbook of Ethnography. London: Sage.

Malinowski, B. C. 1922. 'Ethnology and the Study of Society', Economica, 2:20819.

— 1926. 'Anthropology', Encyclopedia Britannica 13th edition:131-40.

— 1929a. 'Social Anthropology', Encyclopedia Britannica 14th edition: 862-70.

- 1929b. Review of Gunnar Landman, The Kiwai of British New Guinea', Folklore, 40:109-12.

— 1932. 'Introduction' to Reo Fortune, Sorcerers of Dobu. London: George Arnold.

Marcus, G E. and R. Cushman 1982. 'Ethnographies as Text', Annual Review of Anthropology, 11: 25-69.

Mead, M. 1952. 'The Training of the Cultural Anthropologist', American Anthropologist, 54:343-46.

Murdock, G. P. 1952. 'British Social Anthropology', American Anthropologist, 53: $465-73$.

Petermann, W. 2004. Die Geschichte der Ethnologie. Wuppertal: Peter Hammer Verlag

Quiggin, A, H, 1942. Haddon the Headhunter. Cambridge: Cambridge University Press.

Radcliffe-Brown, A. R. 1931. The Social Organisation of Australian Tribes. Sydney: Oceania Monographs, No 1. 
— 1951. 'Review of E. E. Evans-Pritchard's Social anthropology', British Journal of Sociology, 2:364-66.

— 1952. 'Historical Note on British Social Anthropology', American Anthropologist, 54: 275-77.

1958 [orig. 1931]. 'The Present Position of Anthropological Studies', in M. N. Srinivas (ed.), Method in Social Anthropology: Selected Essays by A. R. Radcliffe-Brown. Chicago: University of Chicago Press.

Radin, P. 1965 [1933]. The Method and Theory of Ethnology: an Essay in Criticism. New York: Basic Books.

Richards, A. I. 1950. 'Some Types of Family Structure amongst the Central Bantu', in A. R. Radcliffe-Brown and Darryl Forde eds, African Systems of Kinship and Marriage. London: Oxford University Press.

Risjord, M. 2000. 'The Politics of Explanation and the Origins of Ethnography', Perspectives on Science, 8:29-52.

Risley, H. 1911. 'The Methods of Ethnography', Journal of the Royal Anthropological Institute, 41: 8-19.

Rivers, W.H. R. 1914. The History of Melanesian Society. Cambridge: Cambridge University Press.

Sangren, S. 1988. 'Rhetoric and the Authority of anthropology: 'Postmodernism', and the Social Reproduction of Text', Current Anthropology, 29:405-35.

Schapera, I. 1930. The Khoisan Peoples of South Africa: Bushmen and Hottentots. London: Routledge.

'Science Notes: Anthropology', The Academy, 11, 24 March 1877: 255.

Spencer, J. 1989. 'Anthropology as a Kind of Writing', Man 24:145-64.

— 2001. 'Ethnography after Postmodernism', in Paul Atkinson et al. (eds), Handbook of Ethnography. London: Sage.

Stocking, G.W. Jr. 1968. Race, Culture and Evolution: Essays in the History of Anthropology. New York: The Free Press. 
1987. Victorian Anthropology. New York: The Free Press.

— 1996. After Tylor: British Social Anthropology 1888-1951. Madison: Wisconsin University Press.

- 2001a. 'Reading the Palimpsest of Inquiry: Notes and Queries and the History of British social anthropology', in his Delimiting Anthropology: Occasional Inquiries and Reflections. Madison: Wisconsin University Press.

- 2001b. 'Franz Boas and the History of Humanistic Anthropology', in his Delimiting Anthropology: Occasional Inquiries and Reflections. Madison: Wisconsin University Press

— 2001c. 'Delimiting Anthropology: Historical Reflections on the Boundaries of a Boundless Discipline', in his Delimiting Anthropology: Occasional Inquiries and Reflections. Madison: Wisconsin University Press.

Strathern, M. 1987. 'Out of Context: The Persuasive Fictions of Anthropology', Current Anthropology, 28: 251-80.

Tax, S et al. eds, 1953. An Appraisal of Anthropology Today. Chicago: Chicago University Press.

Thomas, N. 1989. 'The Force of Ethnology: Origins and Significance of the Melanesia/Polynesia division, Current Anthropology, 30: 27-34.

— 1991. 'Against Ethnography', Cultural Anthropology, 6:306-22.

— 1997. 'Melanesians and Polynesians: Ethnic Typifications Inside and Outside Anthropology', in his In Oceania: Visions, Artifacts, Histories. Durham: Duke University Press.

Topinard, P. 1878. Anthropology. London: Chapman.

Urry, J. 1984. 'A History of Field Methods', in R. F. Ellen (ed.) Ethnographic Research: a Guide to General Conduct, 35-61. London, Academic Press.

— 1985. 'Ethnographic Fieldwork: A Brief History of the Central Anthropological Initiation rite, Sites: a Journal for Radical Perspectives on Culture, 11: 6-12. 
— 1993. Before Social Anthropology: Essays on the History of British Anthropology. Reading: Harwood Academic Publishers.

Vermeulen, H. F. 1995. 'Origins and Institutionalisation of Ethnography and Ethnology in Europe and the USA, 1771-1845', in Han F. Vermeulen, and Arturo Alvarez Roldán eds Fieldwork and Fieldnotes. Studies in the History of European Anthropology. London: Routledge.

Young, M. W. 2004. Malinowski: Odyssey of an Anthropologist 1884-1920. New Haven and London: Yale University Press. 